\author{
Cadernos de \\ ESTUDOS LNGUUISTICOS - (58.2), Campinas, pp. 237-256 - mai./ago. 2016
}

\title{
FROM EUROPEAN TO BRAZILIAN PORTUGUESE: A PARAMETER TREE APPROACH ${ }^{1}$
}

\author{
JUANITO AVELAR ${ }^{2}$ \\ CHARLOTTE GALVES ${ }^{3}$
}

\begin{abstract}
RESUMO: Neste artigo, apresentamos uma análise para mudanças sofridas pelo português brasileiro relacionadas à concordância e Caso, em contraste com o português europeu. Tomando como base a existência de características sintáticas amplamente atestadas nas línguas bantas, bem como a importância demográfica das populações de origem africana nos períodos colonial e imperial no Brasil, propomos que o português brasileiro é tipologicamente diferenciado do português europeu (e das demais línguas românicas), sob a influência das línguas africanas que entraram em território brasileiro pelo tráfico de escravos. Explorando o quadro teórico da versão minimalista da Teoria de Princípios e Parâmetros, argumentamos que dois parâmetros gramaticais estão crucialmente envolvidos nessa mudança: a possibilidade de expressões nominais serem inseridas sem traço de Caso na derivação de uma sentença, e a ausência de sensibilidade do traço EPP da categoria funcional Tempo à existência de traços-phi. Seguindo o modelo de Roberts (2012), sugerimos que essas propriedades podem ser captadas por meio de uma árvore paramétrica que abarque concordância e Caso.
\end{abstract}

RÉSUMÉ: Dans cet article, nous présentons une analyse de l'évolution du portugais européen vers le portugais brésilien. Prenant comme base l'existence dans celui-ci de caractéristiques syntaxiques amplement attestées dans les langues du groupe bantou, bien comme l'importance démographique au long de l'histoire du Brésil des populations d'origine africaine, nous proposons que le portugais a subi un changement typologique, sous l'influence des langues africaines apportées au Brésil à l'occasion du trafic d'esclaves. Dans le cadre théorique de la version minimaliste de la théorie de Principes et Paramètres, nous argumentons que deux paramètres grammaticaux sont crucialement impliqués dans ce changement: la possibilité pour les expressions nominales d'être insérées dans la derivation sans trait de cas, et l'absence de la sensibilité du trait EPP de la catégorie fonctionnelle Temps à la présence de traits-phi. Adoptant le modèle paramétrique de Roberts (2012), nous suggérons que ces propriétés dérivent d'un arbre paramétrique qui concerne l'accord et le cas.

Mots-clé: Syntaxe du portugais brésilien; changement induit par le contact; arbres paramétriques.

1 This article was partially supported by Fapesp Grant 2012/06078-9 and CNPq Grant 309764/2014-9. We thank Ian Roberts and Jairo Nunes for very helpful comments on previous versions. The remaining errors are ours.

2 juanitoavelar@uol.com.br

33galvesc@unicamp.br 
In this paper, we argue that Brazilian Portuguese has undergone a typological change involving agreement and Case, under the influence of the African languages that were taken to Brazil by the slave trade. We interpret this change in the framework of the parameter network approach proposed by ROBERTS \& HOLMBERG (2010) and ROBERTS (2012).

The paper is organized as follows. In Section 1, we present some syntactic peculiarities that make Brazilian Portuguese a typologically odd language. In Section 2, we introduce the issue of the influence of Niger-Congo languages on Portuguese during the period in which millions of Africans were taken to Brazil by the slave trade. In Section 3, we show that the syntactic properties that distinguish Brazilian Portuguese from the other Romance languages are also found in Bantu languages. Finally, in Section 4, we model the change from European Portuguese to Brazilian Portuguese in the framework of the parameter network. ${ }^{4}$

\section{BRAZILIAN PORTUGUESE: A TYPOLOGICALLY ODD LANGUAGE}

Since the pioneering work by PONTES (1987), it has been commonly accepted that Brazilian Portuguese has a topic-oriented syntax. The more prominent property linked with this status is the so-called topic-subject construction, exemplified in (i) below. In addition to this construction, Brazilian Portuguese presents other particularities involving the subject position, agreement variation and pronouns, which are also exemplified below.

\section{(i) Topic-verb agreement}

Brazilian Portuguese (henceforth BrP), in contrast with European Portuguese (henceforth, EuP), allows for non-canonical agreement between the verb and a preverbal phrase that is not the logical subject, but is generally interpreted as the topic of the sentence. At least two sub-types of non-canonical agreement can be distinguished: agreement with non-argumental locative constituents, as in (1), and agreement with non-argumental possessive constituents, as in (2) - see the list of abbreviations at the end of the paper.

(1) As ruas do $\quad \begin{aligned} & \text { centro não tão } \\ & \text { the.PL streets of }\end{aligned}$ passando carro.
'No cars are passing through downtown.'

${ }^{4}$ Since this paper proposes both a comparative and a diachronic approach, we mean by European Portuguese both the language brought by the Portuguese colonizers in the 16th century and the language still spoken in Portugal. In the traditional periodization of Portuguese (see CASTRO, 2006: 73 for a survey), the former is called "Classical Portuguese" and refers to the period included between the first half of the 16th century and the end of the 18th century. Although the grammar of Classical Portuguese and the grammar of Modern European Portuguese are different in many aspects, they are similar concerning the phenomena considered in this chapter. They can therefore, for our purposes, be grouped under the term "European Portuguese". However, since EP is generally taken as meaning "Modern European Portuguese", we adopt EuP as the abbreviation referring to the larger entity we consider here. 
(2) Aquelas crianças já estão nascendo dente. those children already are born teeth 'The teeth of those children are already growing in.'

(ii) Prepositional subjects

Another BrP construction that is unusual in Romance is found in (3)a., in which the first phrase is a PP, immediately followed by a verb in the 3rd person singular (AVELAR \& CYRINO 2008). Such sentences are interpreted exactly like the b. example, in which the pre-verbal phrase is prepositionless.

(3) a. Na

in-the

minha escola aceita

my school accept.3SG

cartão de crédito

credit card

b. A minha

escola aceita

the my school accept.3SG

cartão de crédito

'My school accepts credit card.'

(iii) Variation in subject-verb agreement

Another important feature of colloquial $\mathrm{BrP}$ is that verbal agreement is variable, as illustrated by the contrast between examples $\mathrm{a}$. and $\mathrm{b}$. below.

(4) a. $A s$

the.PL children

criança(s)

brincavam na varanda.

played.3PL in-the veranda

b. As

criança(s)

brincava

na varanda.

the.PL children played.3SG in-the veranda

'The children played on the veranda.'

(iv) Morphological uniformity in nominative and non-nominative positions

Finally, a last oddity of $\mathrm{BrP}$ with respect to $\mathrm{EuP}$ and other Romance languages is that there is a morphological uniformity between pronouns in nominative and nonnominative positions. We illustrate this fact below with the 2 nd person singular pronoun voce 'you' (cf. 6). It must be noted that there is a variation in object position between the non-case-marked form você and the case-marked form te, as we can see in (6).

(5) Você foi visto na escola.

you.NOM was seen in-the school

'You were seen in the school'

(6) a. A Maria viu você na escola. the Maria saw you.NOM in-the school

b. A Maria te viu na escola. the Maria you.ACC saw in-the school

'Mary saw you in the school.' 


\section{The grammatical properties of $\mathrm{BrP}$}

AVELAR \& GALVES (2011) derive this set of morpho-syntactic facts from two abstract properties. First, they argue that EPP in BrP is $\varphi$-independent (HOLMBERG, 2010). Exploring CHOMSKY's (2008) framework, they argue that in BrP, in contrast with Modern European Portuguese and other Romance languages, Spec- $T$ is created as soon as $T$ is projected, independently of the valuation of the $\varphi$-features of T, which are inherited from C. In EuP, by contrast, Spec- $\mathrm{T}$ is created only after $\mathrm{C}$ is connected to the structure. The representations in (7)a. and (7)b. below show the point of the derivation in which $\mathrm{C}$ is connected to TP and its features are inherited by T, respectively in EuP and BrP. Note that, in Brazilian Portuguese, but not in EuP, the position of Spec-T is already created at this point.

(7) a. European Portuguese

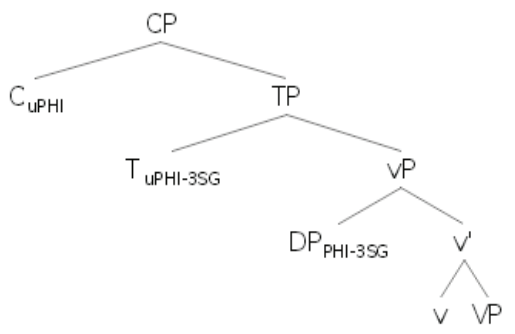

b. Brazilian Portuguese

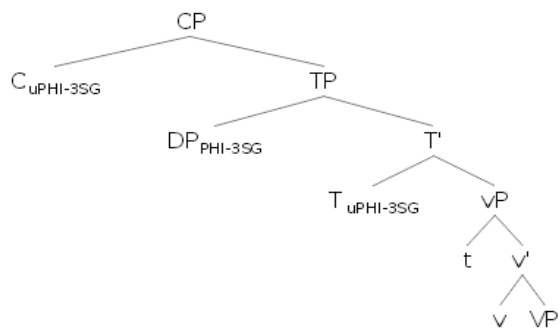

Adopting CHOMSKY's (2008) proposal that A-positions are created by the action of $\varphi$-features, we conclude that, since Spec-T in Brazilian Portuguese can be created without the action of such features, it works as an A'-position in this language. This explains why non-argumental DPs can agree with T's $\varphi$-features in BrP, but not in EuP: since Spec-T is an $\mathrm{A}^{\prime}$-position in BrP and can be created without the action of a $\varphi$-feature probe, non-argumental DPs can occupy this position, which does not occur in EuP.

This analysis accounts for other phenomena in BrP, like the hyper-raising sentence exemplified in (8) below.

(8) Esses carros tão parecendo que o pneu não foi trocado. these cars are seeming that the tyre not was replaced 'It seems that the tyres of these cars were never replaced.'

Our analysis straightforwardly derives the claim by NUNES \& MARTINS (2010) that in BrP instances of hyper-raising, DPs can be moved from SpecTop in the embedded clause to Spec-T in the matrix clause, as represented in (9). This is possible because, due to the fact that Spec-T is an A'-position, the movement from the embedded Spec-Top to the matrix Spec-T is uniform (A'to-A' movement). 
(9) $\left[_{\mathrm{TP}}\left[_{\mathrm{DP}} \text { os carros }\right]_{\mathrm{i}}\left[_{\mathrm{T}}\right.\right.$, parecem ... $\left[_{\mathrm{CP}}\right.$ que $\left[_{\mathrm{TopP}} \mathrm{t}_{\mathrm{i}}\right.$ Top $\left[_{\mathrm{TP}}\left[_{\mathrm{DP}}\right.\right.$ o pneu $\left.\mathrm{t}_{\mathrm{i}}\right]\left[_{\mathrm{T}}\right.$, não foi trocado... $]$

Another property that distinguishes BrP from EuP as well as from the other Romance languages and English has to do with the fact that tough sentences like (10) have two possible interpretations. Interpretation a., by which João is the object of agradar 'please' is the only one allowed in languages like English and EuP. Contrary to these languages, interpretation b., with João as the subject of agradar, is also available in $\operatorname{BrP}$ (Galves, 1987).

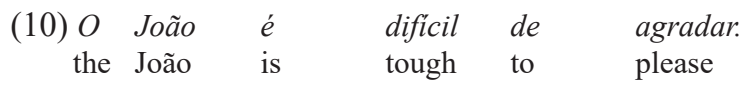

a. 'It is tough to please João'

b. 'It is tough for João to please somebody.'

Interpretation b. of (10) derives from the possibility of the subject of the embedded clause to raise to the subject position of the main clause passing through Spec-C, since this movement is from an A'-bar position to an A'-bar position, as represented in (11). ${ }^{5}$

(11) $\left[_{C P} \mathrm{C}\left[\left[_{T P}\left[\left[_{D P} \text { o João }\right]_{i}\left[{ }_{T}, T \ldots\left[_{C P} t_{i}\left[\left[_{C}\right.\right.\right.\right.\right.\right.\right.\right.$ de $\left[{ }_{T P}\left[t_{v P}\right.\right.$ agradar $\left.\left.\left.\left.\left.\left.]\right]\right]\right]\right]\right]\right]$

Furthermore, in order to account for the optionality of subject agreement and Case marking on pronouns, AVELAR \& GALVES (2011) propose that, in BrP, DPs can be inserted in the derivation without a Case [K] feature. In this condition, pronouns are realized in their default form, and the verbal inflection does not agree. Note that this property is independently required to license the post-verbal DP in sentences like (1)-(2), in which there is a unique source of Case for two DPs.

The interaction of those two properties explains another difference between BrP and EuP. In infinitival clauses introduced by the preposition 'para' (for), as exemplified in (12), the lexical subject can only be morphologically marked as nominative in EuP, while in BrP, it can be either nominative or dative.

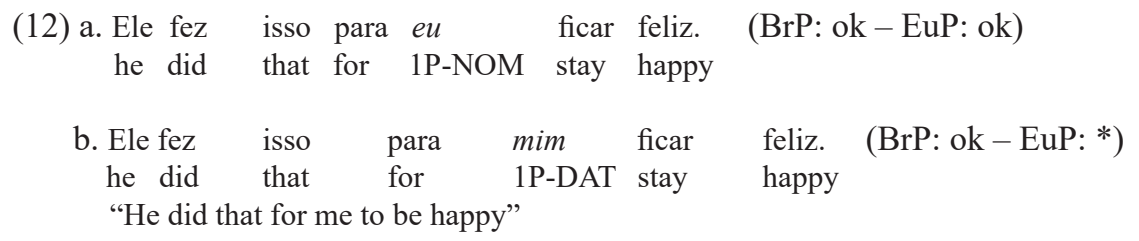

${ }^{5}$ We leave unexplained the possibility of the a. interpretation in all languages. The classical analysis involves a null operator in Comp that is not easily transposable in the current model. 
This contrast can be accounted for by the condition of $\varphi$-(in)dependence of the EPP feature of $T$ in connection with the status of the pronouns with respect to Case. The derivation of the sentences in (12)a-b. in BrP is shown in (13)a-b., respectively, where the preposition para 'for' is the head of the CP projection. Given that the T's EPP is $\varphi$-independent in BrP, the first person pronoun occupies Spec- $\mathrm{T}$ before $\mathrm{C}$ is merged. Assuming that the pronoun can be $[+\mathrm{K}]$ or $[-\mathrm{K}]$, the variation can be explained as follows. When $1 \mathrm{SG}$ is $[+\mathrm{K}]$, the $\varphi$-features of the preposition agree with the pronoun, whose Case is valued as oblique and spelled-out as mim 'me', the oblique form of $1 \mathrm{SG}$. When the pronoun is $[-\mathrm{K}]$, the preposition cannot agree with the pronoun, which is therefore spelled-out as the default form identical to the nominative $\mathrm{eu}$ ' $\mathrm{I}$ '.

$$
\begin{aligned}
& \text { (13) a. }\left[_{\mathrm{CP}} \operatorname{pra}\left[_{\mathrm{TP}} 1 \mathrm{SG}_{\mathrm{K}[\mathrm{OBL}]}(=\operatorname{mim})\left[_{\mathrm{T}}, \mathrm{T}\left[_{\mathrm{V}-\mathrm{VP}} \mathrm{t} \text { ficar feliz }\right]\right]\right]\right] \\
& \text { b. }\left[_{\mathrm{CP}} \text { pra }\left[_{\mathrm{TP}} 1 \mathrm{SG}(=\mathrm{eu})\left[_{\mathrm{T}}, \mathrm{T}\left[_{\mathrm{v}-\mathrm{VP}} \mathrm{t} \text { ficar feliz }\right]\right]\right]\right]
\end{aligned}
$$

The derivation of the sentence in EuP is represented in (14). In this language, Spec- $\mathrm{T}$ is projected only after $\mathrm{C}$ enters the derivation. The $\varphi$-features inherited from $\mathrm{C}$ by $\mathrm{T}$ detect the pronoun in Spec- $v$. In this situation, given that the Case is assigned by $\mathrm{T}$, and not by $\mathrm{C}$, the Case of the pronoun is necessarily valued as nominative.

(14) $\left[_{\mathrm{CP}}\right.$ para $\left[_{\mathrm{TP}} \mathrm{T}\left[_{\mathrm{v}-\mathrm{VP}} 1 \mathrm{SG}_{\mathrm{K}[\mathrm{NOM}]}(=\mathrm{eu})\right.\right.$ ficar feliz $\left.\left.]\right]\right]$

In the next section, we show that the differentiating properties of $\mathrm{BrP}$ are present in Bantu languages.

\section{GRAMMARS IN CONTACT: PORTUGUESEANDAFRICAN LANGUAGES IN BRAZIL}

Taking into account the relevant properties of $\mathrm{BrP}$, one question that arises is how the changes linked to the status of topic-prominent language were triggered. This particular issue can be addressed within a broader debate, which has to do with the question of whether BrP properties emerged from a natural drift of the language or if they result from changes triggered by inter-linguistic contacts. Issues of this nature have led to a polarization of ideas about the origins of BrP. However, this polarization does not seem to take place when the discussion focuses on the patterns of locative inversion and possessor raising: since the clausal patterns exemplified in (1)-(2) are unusual in Romance, we see no reason to explore the hypothesis that we are faced with a change caused by natural drift. As we intend to show, there are strong reasons to believe that such patterns result from changes triggered by inter-linguistic contact involving Portuguese and African speakers of Niger-Congo languages. ${ }^{6}$

${ }^{6}$ The hypothesis that African languages played a crucial role in the emergence of a new variety in Brazil has been recently discussed in different frameworks (cf. for instance NEGRÃO \& VIOTTI, 2011). It is outside the scope of the present paper to present and discuss those analyses, and the theories of contact they rely on. For a survey and a discussion of the issues raised in connection to this debate, we refer the interested reader to AVELAR \& GALVES (2014). 
From a socio-historical perspective, the first point concerns the number of native speakers of African languages brought to Brazil. Historical-demographic surveys show that between the seventeenth and nineteenth centuries, most of the population in different Brazilian regions was formed by Africans and Afrodescendants. MUSSA (1991:163) shows that the contingent of Africans and Afrodescendants in the seventeenth century represented half of the population, as we can see in (15) below. Even suffering a decrease in the following centuries, the percentage of those groups remained relatively high (between $30 \%$ and $40 \%$ ) by the mid-nineteenth century, when the so-called mestiços (mixed-race) came to be the most numerous part of the population.

\begin{tabular}{|l|c|c|c|c|c|}
\cline { 2 - 6 } \multicolumn{1}{c|}{} & $\mathbf{1 5 8 3 - 1 6 0 0}$ & $\mathbf{1 6 0 1 - 1 7 0 0}$ & $\mathbf{1 7 0 1 - 1 8 0 0}$ & $\mathbf{1 8 0 1 - 1 8 5 0}$ & $\mathbf{1 8 5 1 - 1 8 9 0}$ \\
\hline Africans & $20 \%$ & $30 \%$ & $20 \%$ & $12 \%$ & $2 \%$ \\
\hline Afro-descendants & - & $20 \%$ & $21 \%$ & $19 \%$ & $13 \%$ \\
\hline Mixed-race & - & $10 \%$ & $19 \%$ & $34 \%$ & $42 \%$ \\
\hline Euro-descendants & - & $5 \%$ & $10 \%$ & $17 \%$ & $24 \%$ \\
\hline Europeans & $30 \%$ & $25 \%$ & $22 \%$ & $14 \%$ & $17 \%$ \\
\hline Integrated Natives & $50 \%$ & $10 \%$ & $8 \%$ & $4 \%$ & $2 \%$ \\
\hline
\end{tabular}

(Adapted from Mussa 1991: 163)

From a linguistic perspective, the main aspect is the fact that sentences with locative agreement, such as those exemplified in (1), are widespread in Bantu languages, which also exhibit properties related to "orientation to the discourse" (MORIMOTO 2006). Such sentences, exemplified in (16)-(18) below with data from different Bantu languages, have been considered a specific type of locative inversion (SALZMANN 2004), in which a constituent interpreted as a place or direction agrees with the verb, instead of the argumental subject ${ }^{7}$. As pointed out by BAKER (2008), clausal patterns of this type are not found in Indo-European languages (henceforth IE), but are common in the Niger-Congo languages (henceforth NC), including that of the Bantu group. ${ }^{8} 9$

${ }^{7}$ In the examples of Bantu sentences, the numerical characters introduced in the glosses represent noun classifiers or agreement markers on the verb.

${ }^{8}$ It is important to emphasize that, according to BAKER (2008), the properties we are considering here are not exclusive to Bantu languages but extend to all Níger-Congo languages, which constituted the overwhelming majority of the African languages brought to Brazil by the slave trade. There is therefore no issue regarding the question of whether Bantu languages were or were not more important than other African languages with respect to the emergence of Brazilian Portuguese.

${ }^{9}$ Working specifically on genitive constructions, MELO 2014 argues that the existence of such sentences in BrP is not the effect of the influence of African languages but the result of a change undergone by EuP constructions that she calls "external genitive constructions", in which the genitive phrase is a topic doubled by the dative clitic pronoun. This, however, does not invalidate the hypothesis put forth in this paper since constructions in which a genitive phrase is outside of the NP that it is part of are indeed found in many languages, supported by different kinds of syntactic processes. The point we want to emphasize here is that their realization in $\mathrm{BrP}$ is the same as in Niger-Congo languages, i.e., agreement between the moved genitive phrase and the verb. As mentioned in the text, this is completely impossible in EuP and in other Indo-European languages. 
AVELAR \& GALVES - From European to Brazilian Portuguese: A parameter tree approach

(16) KINANDE (BAKER 2003: example 25)

$\begin{array}{lll}\text { Omo-mulongo } & \boldsymbol{m} \boldsymbol{w} \text {-a-hik-a } & \text { (?o-)mu-kali } \\ \text { LOC.18-village } & \mathbf{1 8 S} \text {-T-arrive-FV } & \text { (AUG)-CL1-woman.1 }\end{array}$

'At the village arrived a woman'

(17) OTJIHERERO (MARTEN 2006: p. 98)
mò-ngàndá
$\boldsymbol{m} \boldsymbol{w}$-á-hití
òvá-ndú
18-9.house SC18-PAST-enter
2-people

'Into the house/home entered (the) guests'

(18) KIMBUNDU(http://www.linguakimbundu.com/index3.html)
$\mathrm{Mu}$
njibela
muala
ni
kitadi?
LOC. 18
pocket
LOC18.be with
money
'There is money in the pocket?'

It is important to note that Kimbundu is included among the languages that have the relevant locative inversion pattern (cf. 18). In the literature on slavery in Brazil, Kimbundu is referred to as the language spoken by most of the slaves brought to Brazilian territory. The Grammatica Elementar do Kimbundo ou Lingua de Angola (CHATELAIN, 1888/89) mentions the fact that Kimbundu allows locative agreement, noting that "when, by inversion, the locative precedes the verb, the verbal inflection agrees with it [...]. Conversely, the logical subject loses all influence on the verb, no matter to which class the subject belongs [...]" (p. 89).

With respect to possessor raising, analyses of such clausal patterns in Bantu languages are not as frequent as the ones about locative inversion, but possessorraising sentences similar to the ones found in $\mathrm{BrP}$ are also detected in Bantu languages, as shown by the examples below.

(19) CHICHEWA (SIMANGO 2007: example 23)

Mavuto a-na-f-a

maso

Mavuto SM-PST-die-FV

eyes

'Mavuto became blind' (Lit. 'Mavuto died eyes')

(20) SWAHILI (KEACH \& ROCHEMONT 1994: p. 83)
mtoto
a-li-funik-wa
miguu
1child
1-PST-cover-PASS 4legs
'The child's legs were covered' (Lit. 'The child was covered the legs')

Another similarity between $\mathrm{BrP}$ and Bantu languages concerns the morphological uniformity observed in Case marking. In the previous section, we mentioned the fact that, in $\mathrm{BrP}$, nominative pronouns can be used in nonnominative positions (cf. 5-6). This possibility is reminiscent of a property widely observed among Bantu languages. As noted by CREISSELS (2000: 233), "in the majority of African languages, both subjects and objects are unmarked for case, that is they do not exhibit any marking (affix, adposition or prosodic contour) distinguishing noun phrases in subject and object function from noun phrases quoted in isolation. This is in particular true of the overwhelming majority of 
Cadernos de ESTUDOS LINGUIISTICOS (58.2) - mai./ago. 2016

Niger-Congo languages". About Kimbundu in particular, the grammar of Padre Dias points out that "personal pronouns don't have declinations, nor the variety of cases as Latin pronouns do. They are used in the nominative and in other cases without varying" (2006 [1697]: 8).

The comparison between the syntactic specificities of $\mathrm{BrP}$ presented in Section 1, and the Bantu patterns illustrated in (16-20), strongly suggests that the changes undergone by Portuguese in Brazil were to a great extent induced by contact with African languages spoken by slaves. This is coherent with the demographic data in the table presented in (15), which show that Africans and Afro-descendants corresponded to $60 \%$ of the population from the beginning of the 17 th century up to the middle of the 19th. However, it must be stressed that the proportion of European and white Brazilians was never less than $30 \%$, which explains why, contrary to what was argued by GUY (1981), a Portuguesebased creole did not emerge except in very marginal cases (LUCCHESI et al. 2009:70).

\section{BRPAS A MIXED LANGUAGE AND THE PARAMETER NETWORK APPROACH}

\subsection{A contrast between Bantu and BrP: Object-Verb agreement in OVS clauses}

Despite the similarities between Bantu and BrP observed above, there is an important syntactic difference between them. In (21) below, we see that in Kirundi, as well as in many other Bantu languages, an object can be moved to the pre-verbal position and agree with the verb. This is impossible in BrP, as shown by the ungrammaticality of (22), as well as in IE languages in general.

(21) KIRUNDI (CARTENS 2011: p. 723)

$\begin{array}{lll}\text { Ibitabo } & \text { bi-á-ra-somye } & \text { Johani } \\ \text { 8book } & \text { 8SA-PST-read.PERF } & \text { John }\end{array}$

'John (not Peter) has read (the) books'

(22) * livros leram o João

thePL booksPL readPL the John

'O João leu os livros'

BAKER (2008) tries to capture such differences between IE and NC languages through the Agreement Parameter, established as in (23) below: in IE, the Case feature is crucial to ensuring the agreement of a functional head $\mathrm{H}$ with noun phrases (NP); in NC, it is the locality of the NP that is crucial to ensuring the agreement. 
AVELAR \& GALVES - From European to Brazilian Portuguese: A parameter tree approach (23) Baker's (2008) Agreement Parameter:

(a) A functional head $\mathrm{F}$ agrees with NP only if NP asymmetrically c-commands F. Yes: $\mathrm{NC}$ No: IE

(b) A functional head $\mathrm{F}$ agrees with NP only if $\mathrm{F}$ values the Case feature of $\mathrm{NP}$ or vice versa. No: $\mathrm{NC}$

Yes: IE

According to the Agreement Parameter, the patterns of locative and possessor inversion as presented in (16)-(20) are possible in Bantu because, regardless of where the Case feature is located, the phrase agreeing with T's $\varphi$-features must c-command $\mathrm{T}$. The same explanation is valid for the Bantu OVS sentence presented in (21), wherein the object, not the subject, agrees with the verb.

However, how can we characterize BrP from the point of view of the Agreement Parameter, taking into account that this language behaves like NC with respect to locative inversion, but like IE with respect to OVS?

We have argued that the non-argumental phrase (locative or possessor) raised to Spec- $\mathrm{T}$ is probed by $\mathrm{C}$, valuing its Case as nominative as a result of the valuation of C's $\varphi$-features. This entails that, in BrP, the Agreement Parameter (b) is set to YES. Let us assume therefore that the Agreement Parameter (a) is set to NO. This makes BrP identical to IE languages. In order to derive the relevant similarities with NC languages, we have proposed that DPs can enter the derivation without a Case feature. This is what ensures that the clause is well formed even when the movement of the locative or genitive argument to Spec-T leaves another DP in post-verbal position, with no source for Case-assignment. This is also what allows for the absence of agreement between the verb and its subject, and the indeterminate null subjects with $3^{\text {rd }}$ person singular verbs. As for the impossibility of agreement between $\mathrm{O}$ and $\mathrm{V}$ in OVS, it straightforwardly derives from this analysis. In a language in which agreement is dependent on Case, the object of a transitive verb cannot move to Spec-T and value its Case in this position, hence agreeing with the verb. This is because, when a transitive verb, like ler 'to read', as in (22) above, is present in a derivation, $v \mathrm{P}$ is projected. Inside $v \mathrm{P}, v$ probes the internal argument of the transitive verb, and values its Case as accusative, preventing it from entering another agreement-Case relationship.

Adopting this analysis, the contrast between $\mathrm{NC}$ and $\mathrm{BrP}$ can be summarized in AVELAR \& GALVES' (2011) proposal as follows in (24).

\begin{tabular}{|c|c|c|}
\hline Niger-Congo languages & Brazilian Portuguese & Indo-European languages \\
\hline $\begin{array}{c}\text { Verbal agreement is } \\
\text { established via Spec-Head } \\
\text { relation. }\end{array}$ & $\begin{array}{c}\text { Verbal agreement is } \\
\text { established via probe-goal } \\
\text { relation. }\end{array}$ & $\begin{array}{c}\text { Verbal agreement } \\
\text { isestablished via } \\
\text { probe-goal relation. }\end{array}$ \\
\hline DPs are caseless. & $\begin{array}{c}\text { Case feature is optional } \\
\text { in DPs. }\end{array}$ & $\begin{array}{c}\text { Case feature is } \\
\text { obligatory in DPs. }\end{array}$ \\
\hline
\end{tabular}


The first row of the table in (24) shows Baker's Agreement Parameter reformulated in Chomsky's framework. As expected from a genetic point of view, $\mathrm{BrP}$ is on the side of the IE languages regarding the link between Case and agreement. It is the content of the second row of the table that makes the difference between BrP and IE languages. The optionality of Case-feature in DPs accounts for the absence of morphological agreement in sentence (4a), as well as the possibility of sentences (1)-(2), where the post-verbal DP has no source of Case assignment. This is the abstract property that approximates $\mathrm{BrP}$ to $\mathrm{NC}$ languages. We shall propose below that the fact that T's EPP is $\varphi$-independent, as proposed in section 2, comes for free once the Case parameter is fixed this way. However, $\mathrm{BrP}$ maintains the property of the IE languages with respect to the way verbal agreement is checked when DPs have a Case feature. In this case, DPs are probed either by the $\varphi$-features of $\mathrm{C}$ and receives nominative, or by the $\varphi$-features of $v$, and receives accusative. However, since T's EPP is $\varphi$-independent, DPs that have an unvalued Case feature can be raised to Spec-T before $\mathrm{C}$ is projected. As we have argued above, Spec-T is therefore the position in which those DPs are probed by the $\varphi$-features of $\mathrm{C}$ and consequently have their Case feature valued. This movement is blocked from the complement position of $v \mathrm{P}$, since there is a closer probe, $v$, that is able to value the Case of the DP. ${ }^{10}$ In contrast with BrP, the goal position from T's $\varphi$-feature in EuP, as well as in other IE languages, is Spec- $v$.

\subsection{Parametric trees}

In recent papers, Ian Roberts and Anders Holmberg proposed a new conception of parameters that seeks to reconcile two opposing approaches. One has been advocated by Mark Baker (cf. BAKER, 1996, 2008), who argues that not all differences among languages can be imputed to the effect of features associated with functional categories, as in the so-called Borer-Chomsky (henceforth BC) conjecture. BAKER claims that languages have a "structural genius", defined by SAPIR (1921), the author of Language, as follows:

"This type or plan or structural genius of the language is something much more fundamental, much more pervasive, than any single feature of it we can mention, nor can we gain an adequate idea of its nature by a mere recital of the sundry facts that make up the grammar of the language." (p. 120)

${ }^{10}$ Note that, when the VP internal DP has no case feature, nothing prevents it from raising to Spec-T. But, in this case, no agreement appears on the verb. However, although much more acceptable, OVS order without agreement between the object and the verb is strongly marked. 
From this point of view, macro-differences between languages cannot be traced back to the accumulative effect of micro-parameters associated with functional categories, as suggested by KAYNE (2005). The parametric tree model reconciles the two conceptions in the following way. First, it expresses the claim that macroparameter effects emerge from the accumulative effect of micro-parameters, which in turn are defined as properties of functional categories, as in the BC Conjecture. But, at the same time, it derives the fact, emphasized by BAKER, that consistent languages are more frequent than mixed ones. According to the model, this is not dependent on UG principles but on conservative learning strategies. It is worth emphasizing that, by including learning strategies in the parametric model, this approach is able to make predictions about the direction of change, which was impossible in UG-only based theories of change (cf. LIGHTFOOT 1979). It must be stressed that this conception of parameters is very much influenced by recent developments of the Minimalist Program, which assign to UG only part of the acquisition process. Following CHOMSKY (2005), ROBERTS (2012:321) claims that: "parametric variation is not specified in UG itself. Instead, it arises from underspecified aspects of UG, and is structured by third-factor properties arising largely from the need for efficient learning."

In order to make this exposition more concrete, we present below one of the parametric trees proposed by ROBERTS (2012), which concerns null arguments.

(25) Null arguments parametric tree (ROBERTS, 2012)

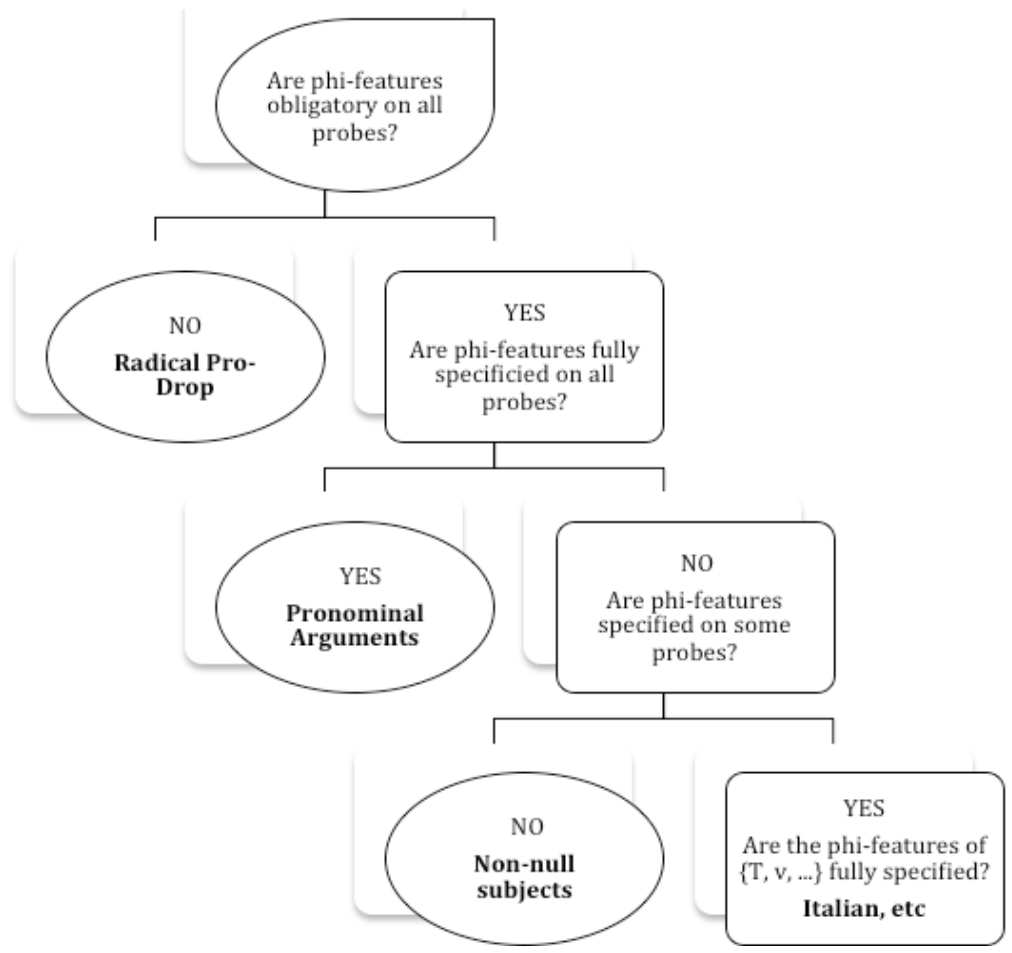


First, we see that the specification of the parameter gets more specific as we go further down the tree. Only at the very bottom does the category T appear. Higher in the tree, there is no reference to specific categories. Second, at the top of the tree lie typological differences (which correspond to macro-parametric differences). In the case of this tree, we find the distinction between languages that have "radical pro-drop" like Chinese, and pronominal argument languages, which are on the opposite side in terms of $\varphi$-feature expression.

As mentioned above, an important property of this model is that it accounts for the direction of change. As ROBERTS (2012: 320) put it, "each parameter hierarchy defines a learning path... with the higher options inherently preferred by the acquirer". Learners only go further down when they are forced to by the linguistic data. This means that in case some evidence is lost or the data become ambiguous, the tendency will be for the acquisition device to stop higher on the tree. Changes are therefore predicted to be upwards. ROBERTS gives several examples to support this claim.

In the next section, we apply this model to the history of Brazilian Portuguese.

\subsection{A model for the change from EuP to BrP}

In what follows, we propose an alternative parametric tree to account for Case-agreement systems in languages. The features concerned are $\varphi$ and Case, which are intrinsically correlated in CHOMSKY $(2001,2008)$ models. ${ }^{11} 12$

11 "For the Case/agreement systems, the uninterpretable features are phi-features of the probe and structural Case of the goal N. phi-features of $\mathrm{N}$ are interpretable; hence, $\mathrm{N}$ is active only when it has structural Case. Once the Case value is determined, $\mathrm{N}$ no longer enters into agreement relations and is "frozen in place" .... Structural Case is not a feature of the probes (T, v), but it is assigned a value under agreement, then removed by Spell-Out from the narrow syntax. The value assigned depends on the probe: nominative for $\mathrm{T}$, accusative for v (alternatively ergative-absolutive, with different conditions). Case itself is not matched, but deletes under matching of phi-features". CHOMSKY, 2001: pp.)

${ }^{12}$ Our formulation of the parameters, namely the use of 'can' does not perfectly conform to the schema proposed in (21). But, it could be easily translated as a quantifier. We leave this question for further research. 

(26) The Agreement-Case Parametric Tree.

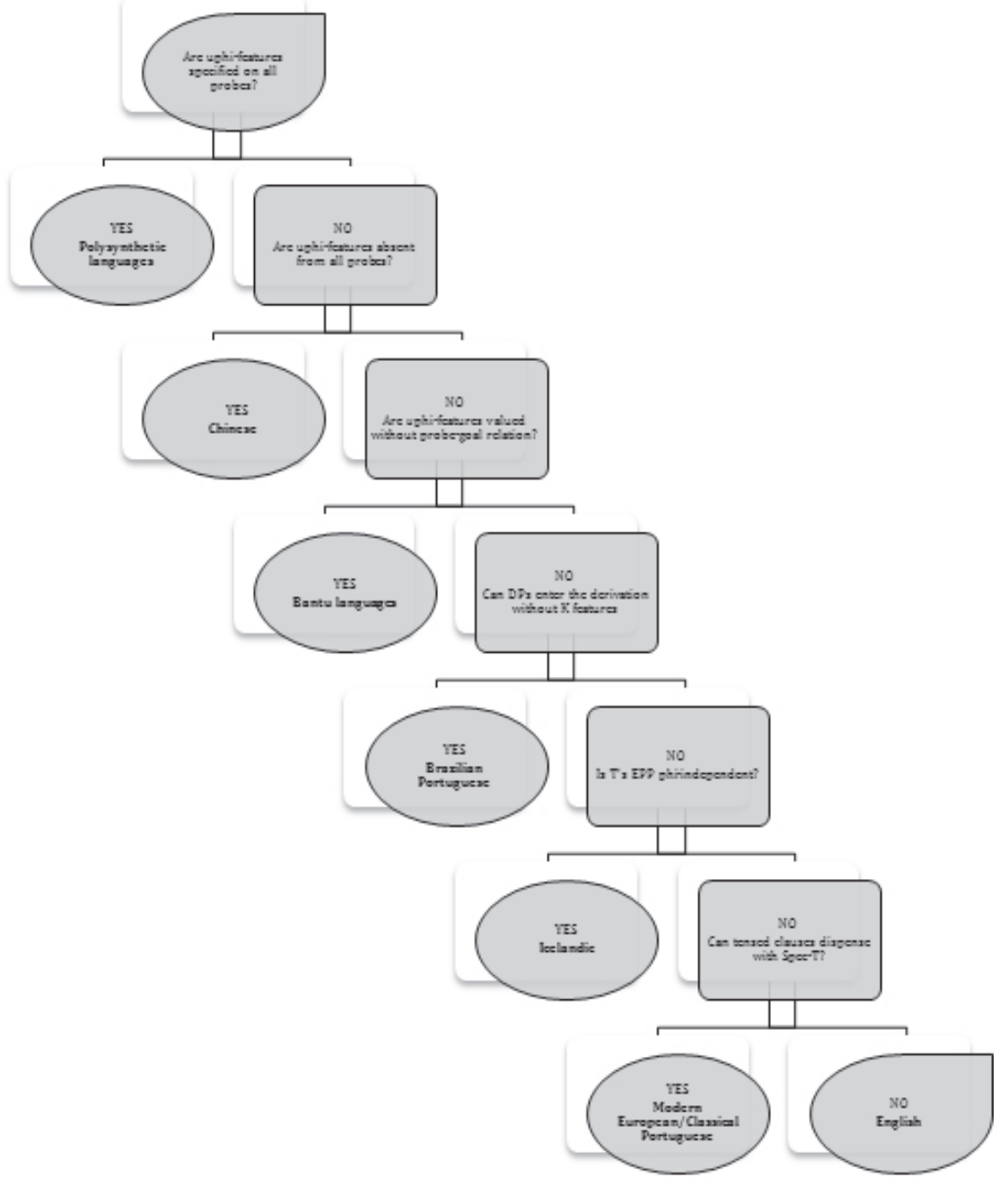

As in figure (25), we distinguish in (26) between the presence vs. the full specification of $\varphi$-features on probes. ${ }^{13}$ But, our tree is different with respect to the location of those two properties. The consequence is that the higher division operated by the parametric tree in (26) is between polysynthetic languages and all the others. This is reminiscent of BAKER (2001: 183, Figure 6.4). We shall discuss below the consequence of this difference with respect to the order of the predictable changes in null subjects.

13 According to ROBERTS (2012: 323), “'fully specified' means recoverably specified, permitting recoverability". 
Cadernos de ESTUDOS LINGUIISTICOS (58.2) - mai./ago. 2016

For languages that are not like Chinese, the next parameter is Baker's Agreement Parameter rephrased in terms of CHOMSKY (2001). We now find the split between IE and NC. The answer NO to this parameter implies the absence of Case features on DPs, because Case valuation depends on feature valuation via the probe-goal relationship. At this point, a comment is required. One property of the parametric tree that is not explored by ROBERTS \& HOLMBERG (2010) and ROBERTS (2012) is the fact that some values assigned to parameters located higher in the tree automatically entail properties that, for other languages, depend on values assigned to parameters lower in the tree. For instance, we derive from the agreement-Case model proposed by CHOMSKY $(2001,2008)$ that languages without $\varphi$-features on their heads, like Chinese, do not have Case features on their DPs. This comes for free. As discussed above, this is also true for languages that have Baker's Agreement Parameter (a) set to NO. But, for languages in which this parameter is set to YES, the question of whether DPs can enter the derivation without a Case feature is, $a$ priori, left open. We can think that the more harmonic solution ${ }^{14}$ is the option NO. However, ambiguous or mixed data can lead children to select YES.

Our claim is that it is what happened in Brazil, under the influence of NC (mainly Bantu) languages. In their acquisition process of Portuguese, Bantu speakers have both transferred properties from their own languages, and missed properties from the target language, mainly the morphological ones. On one side, the absence of subject-verb agreement, or its variation, and the reduction of the pronominal paradigm and, on the other side, the transfer of topic constructions of the kind exemplified in (16)-(20), in which there is no source of Case for one DP, provided evidence that DPs could enter the derivation without the Case feature. Note that one might wonder now why children would not reinterpret Portuguese as a language like Bantu, selecting YES to Baker's Agreement Parameter (a), translated in (26) as 'Are $u \varphi$-features valued without the probe-goal relation?'. ${ }^{15}$ A natural answer is that this is the effect of the constant proportion of native Portuguese speakers in the population, which prevented the second language acquirers and their descendants from completely losing agreement and Case patterns typical of the morphology of Indo-European languages. This is the reason why, from a typological point of view, Brazilian Portuguese became a mixed language.

Coming back to the parametric tree, we can now raise the issue of the relationship between the two parameters we have considered to account for the peculiarities of BrP syntax. We have commented at large on the question of optional K-features on DPs. The other parameter involved is HOLMBERG's (2010) $\varphi$-independence of T's EPP, which accounts for locative and possessor inversion. This parameter is introduced by HOLMBERG to account for the difference between Icelandic and Main Scandinavian Languages. In the former, but not in the latter, are what HOLMBERG calls 'oblique subjects' (2010: 107), as exemplified in (27). Note however that in Icelandic, contrary to BrP, the verb does not agree with the dative subject but with the post-verbal subject. This is expected since Icelandic is a well-behaved IE language, which corresponds to the YES option of Baker's Agreement Parameter.

\footnotetext{
${ }^{14}$ For the notion of harmony, see Roberts (2007).

${ }^{15}$ Note that the agrammaticality of (19) cannot be the answer, since it is negative evidence.
} 
AVELAR \& GALVES - From European to Brazilian Portuguese: A parameter tree approach

\begin{tabular}{rlll}
\hline (27) Mér & voru & gefnar & peninga \\
me & were & given & money $(\mathrm{PL})$
\end{tabular}

The question now is how we can explain the fact that T's EPP is $\varphi$-independent in BrP. Our answer is again that this property comes for free with the parametric choices corresponding to this language. In this case, what is crucial is the fact that BrP allows for DPs without the Case feature. This means that, in some cases, $\mathrm{T}$ has no $\varphi$-features to be valued and the verbal inflection is spelled-out as $3^{\text {rd }}$ person singular (a default morphology mark in BrP), as we have seen in example b. of (4). Since $\varphi$-features to be valued are not an obligatory property of $\mathrm{T}$, there would be a contradiction if T's EPP were $\varphi$-dependent.

In terms of acquisition, this kind of implication is welcome since it helps children fix the parameters of their grammars without having to answer any questions. In fact, each parametric choice strongly narrows down the path to the target grammar. Therefore, even if a parameter is involved in the analysis of a given language, this does not mean that children who acquire this language have to fix this parameter.

Another example of this fact is found in null subjects. It must be noted that all the languages on the left side of the tree in (26) have null subjects. However, only at the very bottom of the tree is the parameter that explicitly expresses the selection between pro-drop languages and non-pro-drop languages. Furthermore, we recover in (26) the distinction between various types of null subject languages also expressed in (25). Without denying that more work is necessary to fully support this claim, we would like to suggest that there is no need for an independent parametric tree concerning null arguments, as proposed by ROBERTS \& HOLMBERG (2010), HOLMBERG (2010) and ROBERTS (2012). The specific behavior of null subjects derives from the different possibilities of association of $\varphi$-features with functional categories. In (26), like in (25), we find both consistent null-subject languages and non-null subjects at the bottom of the tree. In both cases, they represent the less economical choices in terms of the length of the path children must follow. The difference between the two representations lies higher in the trees.

In (26), the partial null subject languages (Icelandic, BrP and Bantu languages) are contiguous to the radical null subject languages (Chinese), while in Figure 2, partial null subject languages are not represented, and the pronominal argument languages are between consistent null subject languages and radical null subject languages. This entails different predictions with respect to the order of possible changes affecting null subjects. Here, it is worth noting that $\mathrm{BrP}$ is a partial null subject language (cf. RODRIGUES 2002, HOLMBERG \& SHEEHAN 2010, among others), while EuP is a consistent null subject language. The change from EuP to $\mathrm{BrP}$ is a change from a consistent to a partial null subject language. Since partial and radical null subjects look very similar to one another, ${ }^{16}$ their contiguity in the tree seems natural.

\footnotetext{
${ }^{16}$ This is, at least, what can be inferred from the comparison between Chinese and BrP. However, more comparative work must be performed in order to understand the subtle differences between the various kinds of partial null subject languages (cf. several chapters in BIBERAUER et al., 2010) and radical pro-drop languages.
} 


\section{CONCLUDING REMARKS}

In this paper, we have analyzed the change from EuP to BrP. We have argued that the parameters crucially involved in the change were: 1) the possibility for DPs to be generated without the Case feature, and 2) T's EPP $\varphi$-independence (HOLMBERG, 2010). Following the work of ROBERTS \& HOLMBERG (2010) and ROBERTS (2012), we have considered those parameters to be part of an Agreement/Case parametric tree that also include " $\varphi$-feature full specification", "absence of $\varphi$-features", "valuation of $\varphi$-features under probe-goal relation", and, at the very bottom, "projection of Spec-T". We have argued that, in the network determined by such a tree, the parameters are in an inclusion relation, meaning that, except for the root, the YES value to a parameter $\mathrm{X}$ implies the YES value to the parameters $\mathrm{Y}$ dominated by $\mathrm{X}$. This is a slight extension of the model proposed by ROBERTS \& HOLMBERG, which makes their approach to parametric variation and change still more attractive from the point of view of acquisition: it is possible to derive from this picture the fact that many properties of the attained language come for free once a given parameter is fixed. Note that this is reminiscent of the first formulations of parameters, i.e., the fixation of the value of one parameter is at the origin of the acquisition of several properties. As observed by ROBERTS \& HOLMBERG, this proposal has been seriously challenged. But, if we are on the right track, parameter trees are able to recover that crucial result.

Furthermore, our analysis has consequences for the pro-drop hierarchy. The difference of our approach from that of ROBERTS \& HOLMBERG is that null arguments, and in particular null subjects, do not need to be acquired via a specific parametric tree. Our proposal is that they depend to a great extent on the way $\varphi$-features are, or are not, associated with functional categories. We argue that only consistent null subjects are dependent on a specific parameter.

As we have shown, it is very likely that the main syntactic peculiarities of $\mathrm{BrP}$ are due to language contact. This claim is supported both by the demographic history of Brazil and by the similarities between $\mathrm{BrP}$ and Bantu languages. Additional evidence is found in the similarities between BrP and Portuguese spoken in Africa, both as first and as second languages (cf. PETTER 2009). Language contact strongly favors language change because it creates ambiguous primary linguistic data (PLD) of two types. One type of ambiguity is due to the existence of more than one language in the environment. The other type of ambiguity derives from the interference of one language with the other due to imperfect learning. According to ROBERTS (2007), ambiguities lead to reanalysis, which leads to more economical structures (see also ROBERTS \& ROUSSOU, 2003). The grammars that are defined by parameters more embedded in the tree are more marked than grammars that are defined by parameters less embedded in the tree, because their parametric description is longer. The prediction, then, is that the direction of change is from more embedded grammars to less embedded grammars. This is what we propose for the emergence of BrP. Additionally, we obtain a configuration in which languages are disposed in accordance with their typological membership. In (26), BrP is both higher in the tree and closer to Bantu languages. This nicely expresses its typologically mixed nature. On one hand, it fixes the value of the 
AVELAR \& GALVES - From European to Brazilian Portuguese: A parameter tree approach

Agreement Parameter like Indo-European languages; on the other hand, it behaves to a great extent like Bantu languages. Finally, the analysis proposed in this chapter also accounts for the great amount of syntactic variation found in BrP. As far as agreement and Case are concerned, we derive variation without the need to appeal to grammar competition. ${ }^{17}$ This does not imply that such a variation is not socially governed, since formal education still has a great influence on it. However, our claim is that the variants are produced by the same grammar.

\section{ABREVIATIONS}

$\begin{array}{ll}\text { AUG } & =\text { augmentative vowel } \\ \text { CL } & =\text { noun classifier prefix } \\ \text { DAT } & =\text { dative } \\ \text { FV }, \text { fv } & =\text { final vowel } \\ \text { LOC } & =\text { locative affix / adposition / clitic } \\ \text { NOM } & =\text { nominative } \\ \text { P } & =\text { person } \\ \text { PASS } & =\text { passive voice } \\ \text { PAST, PST } & =\text { past } \\ \text { PERF } & =\text { perfective } \\ \text { PL } & =\text { plural } \\ \text { S, SA, SC, SM } & =\text { subject-verb agreement marker } \\ \text { SG } & =\text { singular } \\ \text { T } & =\text { tense }\end{array}$

\section{REFERENCES}

AVELAR, Juanito and Charlotte Galves. 2011. "Tópico e concordância em português brasileiro e português europeu". In: Armanda Costa; Isabel Falé; Pilar Barbosa (eds.) Textos Seleccionados: Actas do XXVI Encontro Nacional da Associação Portuguesa de Linguística (Porto, 2010), 2011, pp. 49-65.

AVELAR, Juanito and Charlotte Galves. 2014. O papel das línguas africanas na emergência da gramática do português brasileiro. Revista Linguística (Online), v. 30, pp. 241-288, Baker, Mark. 1996.

AVELAR, Juanito and Sonia Cyrino. Locativos preposicionados em posição de sujeito: uma possível contribuição das línguas Bantu à sintaxe do português brasileiro. Revista de Estudos Linguísticos da Universidade do Porto, Vol. 3, pp. 55-75. 2008.

BAKER, Mark. 2001. The Atoms of Language. New York: Basic Books.

BAKER, Mark. 2003. Agreement, dislocation, and partial configurationality. In: A. Carnie; H. Harley; M. Willie (Eds.). Formal Approach to Function. Amsterdam: John Benjamins, pp.107-134.

${ }^{17} \mathrm{We}$ do not mean that this is always true. For instance, a well-established case of grammar competition in BrP is found in clitic placement (cf. CORREA, 1991; CARNEIRO \& ALVES, 2010). 
BAKER, Mark. 2008. The macroparameter in a microparametric world. In: T. Biberauer (ed.) The limits of syntactic variation. Amsterdam, Benjamins, pp. 351-374.

BIBERAUER, Thereza, Anders Holmberg, Ian Roberts and Michelle Sheehan (eds) Parametric Variation: Null subjects in Minimalist Theory. Cambridge: Cambridge University Press.

CARNEIRO, Zenaide \& Charlotte Galves. 2010. "Variação e Gramática: colocação de clíticos na história do português brasileiro". Revista de Estudos da Linguagem 18, 1: 7-38.

CARNSTENS, Vicky. 2011. Hyperactivity and hyperagreement in Bantu. Lingua 121: 721-741.

CASTRO, Ivo. 2006. Introdução à história do português. Lisbon: Edições Colibri.

CHATELAiN, Heli. Grammatica Elementar do Kimbundu ou Lingua de Angola. Genebra: Typ. De Charles Schuchardt. 1889.

CHOMSKY, Noam. 2001. Derivation by phase. In: M. Kentowitcz (ed.) Ken Hale: a life in language. Cambridge (MA): MIT Press, pp.1-53.

CHOMSKY, Noam. 2005. Three factors in language design. Linguistic Inquiry 36: 1-22.

CHOMSKY, Noam. 2008. On phases. In R. Freidin, C. Otero and M. L. Zubizarreta (eds.) Foundational issues in linguistic theory. Cambridge (MA): MIT Press, pp. 133-166.

CORREA, Vilma. 1991. O objeto direto nulo no português do Brasil. Unpublished Master Thesis, University of Campinas.

CREISSELS, D. 2000. Typology. In: B. Heine \& D. Nurse. African languages: an introduction. Cambridge: Cambridge University Press, pp. 231-258.

DIAS, Pedro. 2006 [1697]. A arte da lingua de Angola. Edição fac-similar. Rio de Janeiro: Fundação Biblioteca Nacional.

GALVES, Charlotte. 1987. A sintaxe do português brasileiro, Estudos de Linguística, 13, Belo Horizonte. (reprinted in Ensaios sobre as gramáticas do português, Campinas, Editora da Unicamp, 2001).

GONÇALVES, Perpétua. 2010. A gênese do português de Moçambique. Lisboa: Imprensa Nacional Casa da Moeda.

GUY, Gregory. 1981. Linguistic variation in Brazilian Portuguese: aspects of phonology, syntax and language history. Unpublished PhD Dissertation University of Pennsilvania.

HOLMBERG, Anders. 2010. "Null subject parameters". In: Biberauer et al. (eds.) pp. 88-124.

HOLMBERG, Anders and Michelle Sheehan. 2010. "Control into finite clauses in partial null-subject languages" In: Biberauer et al. (eds.) pp. 125-152.

KAYNE, Richard. 2005. 'Some Notes on Comparative Syntax'. In Movement and Silence, Oxford: Oxford University Press, pp. 277-333.

KEACH, Camillia N. and Michael Rochemont. 1994. On the syntax of possessor raising in Swahili. Studies in African Linguistics, 23(1). pp. 81-106.

LIGHTFOOt, David. (1979) Principles of Diachronic Syntax. Cambridge: Cambridge University Press. 
AVELAR \& GALVES - From European to Brazilian Portuguese: A parameter tree approach

LUCCHESI, Dante, Allan Baxter and Ilza Ribeiro (2009) O português afro-brasileiro. Salvador: Editora da UFBa.

MARTEN, Lutz. 2006. Locative inversion in Otjiherero: more on morphosyntactic variation in Bantu. ZAS Papers in Linguistics, 97-122.

MELO, Elaine Alves Santos. A influência bantu nas construções de tópico-sujeito: a marcação de posse [DP+DP]. Textos seleccionados - XXIX Encontro da Associação Portuguesa de Linguística. Porto: APL, pp. 361-379. 2014.

MORIMOTO, Yukiko. Agreement properties and word order in comparative Bantu. ZAS Papers in Linguistics 43, pp. 161-187. 2006.

MUSSA, Alberto. 2011. O papel das línguas africanas na história do português do Brasil. Master thesis. Universidade Federal do Rio de Janeiro.

NEGRÃO, Esmeralda and Evani Viotti. 2011. Epistemological aspects of the study of the participation of African languages in Brazilian Portuguese. In: M. Petter, e M. Vanhove (eds.), Portugais et langues africaines. Études afro-brésiliennes, Paris, Karthala: 13-44.

NUNES, Jairo and Ana Maria Martins. 2010. Apparent hyper-raising in Brazilian Portuguese: agreement with topics across a finite TP. In. Phoevo Panagiotidis (org.) The complementizer phase: subjects and operators. Oxford: Oxford University Press, pp. 143-163.

PETTER, Margarida. O continuum afro-brasileiro do português. In: C. Galves, H. Garmes \& F. Ribeiro (eds.). Africa-Brasil: caminhos da língua portuguesa. Campinas: Editora da Unicamp, pp. 158-173, 2009.

PONTES, Eunice. 1987. O tópico no português do Brasil. Campinas: Pontes.

ROBERTS, Ian. 2007. Diachronic syntax. Oxford: Oxford University Press.

ROBERTS, Ian. 2012. "Macroparameters and minimalism: a programme for comparative research". In: Galves et al. (eds) Parameter Theory and Linguistic Change, Oxford: Oxford University Press, pp. 319-334.

ROBERTS, Ian and Anders Holmberg. 2012. "Introduction: parameters in Minimalist Theory". In: Biberauer et al. (eds.), pp. 1-57.

ROBERTS, Ian, \& Anna Roussou. 2003. Syntactic Change: A Minimalist Approach to Grammaticalization. Cambridge: Cambridge University Press.

RODRIGUES, Cilene. 2002. Morphology and null subjects in Brazilian Portuguese. In: D. Lightfoot (ed.) Syntactic effects of morphological change. Oxford: Oxford University Press, pp. 160-78.

SALZMANN, Martin. Theoretical approaches to locative inversion. MA Dissertation. Philosophical Faculty of the University of Zurich. 2004.

SIMANGO, Silvester Ron. 2007. Enlarged arguments in Bantu: evidence from Chichewa. Lingua 117(6): 928-949. 